6. Kontseptsiia diialnosti tsentriv osvity tretoho viku v Ukraini [Tekst] : [metod posib.] / [avt. -uklad.: A. Yu. Horbovyi ta in; pid zah. red.: D. P. Spulber, A. Yu. Horbovyi, A. A. Khaletska] ; DVNZ "Kyiv. nats. ekon. un-t im. Vadyma Hetmana", Ukr. in-t rozvytku fond. rynku. - Kyiv : UIRFR, 2017. - $115 \mathrm{~s}$.

7. Kontseptsiia osvity doroslykh v Ukraini/ ukl.: L. B. Lukianova. - Nizhyn: P P Lysenko M. M., 2011. $-24 \mathrm{~s}$.

8. Finikov T.V., Sharov O.I., Shchepetylnykova Ye.Ie., Smyrnov O.O., Lotariev A.H., Mobilnist naukovo-pedahohichnoho personalu // Monitorynh intehratsii ukrainskoi systemy vyshchoi osvity v Yevropeiskyi prostir vyshchoi osvity ta naukovoho doslidzhennia: monitorynh. doslidzh. : analit. zvit / Mizhnarod. blahod. Fond "Mizhnarod. Fond doslidzh. osvit. polityky" ; za zah. red. T.V.Finikova, O.I.Sharova- K. : Takson, 2014. - S. 127-129.

9. Kontseptsiia vprovadzhennia media-osvity v Ukraini. Skhvaleno postanovoiu Prezydii Natsionalnoi akademii pedahohichnykh nauk Ukrainy 20 travnia 2010 roku, protokol № 1-7/6-150 https://ru.calameo.com/books/00198748896c858cae696

10. Klopov R. V. Henezys dystantsiinoho navchannia / R. V. Klopov // Pedahohichnyi protses: teoriia i praktyka. - K., 2005. - Vyp. 2. - S. $37-46$.

11. Zmeev S.Y. Andrahohyka: osnovyi teoryy, ystoryy y tekhnolohyy obuchenyia vzroslyikh. - M.: M.: PER SЭ, 2007. - S. 91. $-272 \mathrm{~s}$.

12. Sihaieva L. Ye. Rozvytok osvity doroslykh v Ukraini (druha polovyna KhKh - pochatok KhKhl st.): [monohrafiia] / za red. S. O. Sysoievoi. - K.: EKMO, 2010.- $420 \mathrm{~s}$.

13. Kuchai $\mathrm{O}$. V. Vykorystannia multymediynykh tekhnolohiy u pidhotovtsi vchyteliv pochatkovykh klasiv : navchalnyy posibnyk. - Cherkasy : vydavets Chabanenko Yu. A., 2015. I 52 s.

14. Oliinyk V.Osvita vprodovzh zhyttia: yak i choho vchyty doroslykh? // Upravlinnia osvitoiu - 2010. № 1 (229). - S 4-7

Одержано статтю: 5.02 .2019

Прийнято до друку: 19.03.2019

УДК 37.012:929:930(045)

DOI:10.15330/esu. $15.45-51$
Ірина Розман,

кандидат педагогічних наук, доцент,

Мукачівський державний університет

(м. Мукачево, Україна)

Iryna Rozman,

Candidate of pedagogical sciences $(\mathrm{PhD})$,

Associate Professor, Mukachevo State University

(Mukachevo, Ukraine)

rozmanii@ukr.net

\title{
ПЕДАГОГІЧНА БІОГРАФІСТИКА: ДЖЕРЕЛОЗНАВЧИЙ АСПЕКТ
}

\section{PEDAGOGICAL SCIENCE OF BIOGRAPHY: SOURCE-STUDY ASPECT}

У статті розглянуто проблему чіткого розмежування понять “автентичне периоджерело” (як “джерело-факт”, “джерело-подія”) та “історіографічне джерело” як різновид науково-аналітичних студій. Обтрунтовано думку щодо необхідності класифікачій історико-педагогічних джерел вивчення біографістики. Констатовано, ио, коли дослідник визначас типову структуру джерельної бази історико-педагогічного досліджения, відбувається виокремлення в ній трьох основних груп матеріалів. Зазначено, ще міждисчиплінарність біографістики зумовлюе потребу використання науковометодологічного інструментарію не лиие історико-педагогічної науки (яка спирається на досвід історичної науки), а й іниих галузей знань: психології, сочіології, лінгвістики, історії.

Ключові слова: джерелознавча проблема, досліджения, класифікачія, історикопедагогічний прочес. 
The article deals with the problem of clear separation of "authentic source" concepts (as "ource-fact", "source-event") and "historiographic source" as a kind of scientific and analytical studies. The opinion on the necessity of classification of historical and pedagogical sources of studying biography is grounded. It is emphasized that historical and pedagogical sources are divided into narrative and didactic. An origin history of a certain set of sources has been made, which actualizes and determines the guidelines for the structural and functional analysis of its source-study aspect.

It was stated that determining the typical structure of the source base of historical and pedagogical research, there was a selection of three main groups of materials in it. It is noted that the interdisciplinarity of science of biography necessitates the use of scientific and methodological toolkit not only of historical and pedagogical science (based on the experience of historical science), but also of other branches of knowledge: psychology, sociology, linguistics, history.

The necessity of structurally-individual analysis of the personality, which allows to generalize scientific experience and to plan an approach to the consistent study of personality, is substantiated. Focused attention on the development and formation of the psychosocial structure of the individual. It is noted that the impact on life and the creative and professional "portrait" of the person is replenished or interchangeable with certain psychic traits. The emphasis is placed on the fact that in the study of pedagogical personnel it is necessary to pay special attention to the influence of temperament on the development of a separate person.

It has been found out that there are motives and incentives that, on the one hand, characterize the orientation and attitude of the person to a certain subject, phenomenon, social environment, on the other hand, are the driving force for learning, self-education, creative and other activities.

Key words: source-study problem, research, classification, historical and pedagogical process.

Постановка проблеми. В українській історико-педагогічній науці джерелознавча проблема актуалізувалася в середині 90-х рp. XX ст. у зв'язку зі розширенням доступу до документальних матеріалів, завдяки зняттю грифу “секретно" з архівних і бібліотечних “спецфондів" та студій українського зарубіжжя і зарубіжних авторів. На такому тлі виник, за словами О. Сухомлинської, один iз важливих чинників трансформаційної кризи сучасної історії педагогіки джерелознавчий. До історико-педагогічного дискурсу стали долучати багато нового, хоча й частково відомого матеріалу, на який за радянського періоду було накладене “табу” або він оцінювався негативно. Виникла ситуація, коли величезний масив першоджерел "науково не віддеференційовувався, не відрефлексовувався", не структурувався, а тексти досліджень стали “потопати у фактологіï". Це актуалізувало потребу адекватної оцінки джерел різного походження, які “становлять дискурсивну тканину часу" [10, с. 27].

Аналіз досліджень і публікацій. Теоретичну основу дослідження педагогічної біографістики становить доробок українських i зарубіжних учених: 3 методології дослідження педагогіки (I. Аносов, Л. Артамошкін, М. Берулава, Б. Бім-Бад, А. Закірова, I. Зязюн, Н. Іпполітова, М. Каган, В. Краєвський, Г. Кузьменко, В. Кремень, В. Лаппо, В. Луговий, О. Невмержицька, О. Новіков, В. Онищенко, А. Сбруєва, С. Сисоєва, Н. Скотна, Н. Ткачова та ін.), історії педагогіки (О. Адаменко, В. Безрогов, С. Бобришов, М. Богуславський, Л. Ваховський, А. Вихрущ, С. Гончаренко, Н. Дічек, О. Сухомлинська, С. Хриков та ін.). Значний науково-теоретичний i практичний досвід дослідження педагогічних персоналій акумулюють близько 160 захищених в Україні у другій половині XX - на початку XXI ст. докторських i кандидатських дисертацій та понад 80 колективних, 
індивідуальних монографій і навчальних посібників, безліч журнальних статей i публікацій матеріалів наукових конференцій, антологій, бібліографічних i біобібліографічних видань, інших видів літератури, що з'явилися за цього часу.

Мета статті - 3'ясувати аналіз джерел дослідження педагогічних персоналій.

Виклад основного матеріалу. Кожне історико-педагогічне дослідження передбачає використання певної сукупності джерел для розв'язання висунених завдань. Тому “джерелознавча проблема" $\epsilon$ універсальною, всеохопною та супроводжує всі етапи науково-дослідницької праці й значною мірою зумовлює іiі зміст, структуру, обгрунтованість теоретичних положень і висновків, отже, якість і цінність загалом. Вона цілком логічно розглядається в розрізі розробки теоретикометодологічних засад дослідження, а науковий дискурс навколо неї відстежусмо із 70-х pp. ХХ ст., коли радянські історики педагогіки почали предметно розробляти методику збору й аналізу іiі джерельних матеріалів [3, с. 145-156; 6, с. $143 ; 2$, с. $185 ; 8$, c. $85-98]$

Це, своєю чергою, зумовило становище, коли науковці, виходячи із предмета $\mathbf{i}$ завдань своїх конкретно-тематичних досліджень, стали на власний розсуд розробляти класифікації їхнього джерельного корпусу. При цьому вони спиралися на різні, часто довільно дібрані критерії або взагалі ігнорували використання цього методологічного інструменту. 3 нашого погляду, першим кроком до розв'язання цієї проблеми має стати чітке розмежування понять “автентичне першоджерело” (як “джерело-факт", “джерело-подія") та "історіографічне джерело" як різновид науково-аналітичних студій, на що, до слова, вказують окремі дослідники [9, с. 42].

Означена проблема має свої гносеологічні коріння, зумовлені науковою традицією у підходах до класифікації історико-педагогічних джерел. Вона сформувалася в лоні радянської науки в 70-80-х pp. XX ст., хоча вже тоді чимало науковців чітко вирізняли джерела не лише за формальними, а й за сутнісно-змістовими ознаками. Зокрема, до сьогоднішнього дня, залишається популярною розроблена Д. Раскіним [8] класифікація історико-педагогічних джерел; на неї спирається Н. Гупан, поділяючи їх на оповідальні (наукові, історичні, публіцистичні праці); дидактичні (підручники, посібники); документальні [5, с. 9]. Така постановка питання сприйнятлива, якщо поняття "історико-педагогічне джерело" розуміти як "загальне", “універсальне”, “родове”, у якому, підкреслюємо, слід вирізняти “першоджерело” як первинний документ, що не $\epsilon$ результатом наукової рефлексії, від “історіографічного джерела", що є формалізованим виявом науково-аналітичної думки, позиції, твердження. Між тим, як показали результати нашого історіографічного аналізу досліджень 3 педагогічної біографістики, науковці переважно не дотримуються такого поділу. Цей висновок частково підтверджує здійснений О. Петренко аналіз класифікацій джерельної бази в сучасних історико-педагогічних дослідженнях [7].

Простежуємо ситуацію, коли й у спеціальних науково-теоретичних студіях при здійсненні “класифікації джерел історіографії педагогічної персоналіі” автори вирізняють "оповідальні джерела" та їні окремі види: наукові (монографії, статті тощо); публіцистичні (статті, виступи і т. ін.); особового походження; критикобібліографічні; художньо-педагогічні [4, с. 164].

Означений у руслі наукового дискурсу комплекс питань стосується педагогічної біографістики та актуалізує i визначає орієнтири структурнофункціонального аналізу iii джерелознавчого аспекту. При цьому виходимо із означених ученими методологічних позицій. З'ясовуючи проблему добору, використання, аналізу джерел історії педагогіки, О. Сухомлинська (2008) виокремила 
розвиток “нової наукової дисципліни” - історико-педагогічної історіографії та вказала, що “вивченням принципів і методів роботи 3 джерелами має займатися історико-педагогічне джерелознавство" [10, с. 367]. Тобто фактично йдеться про розмежування цих аспектів історико-педагогічного дослідження.

Визначаючи "типову структуру джерельної бази історико-педагогічного дослідження“, О. Адаменко [1] виокремила в ній три основні групи матеріалів, які: 1) обгрунтовують його методологію; 2) становлять його теоретичну основу (публікації і дисертації за науковою проблемою); 3) є автентичними джерелами, тобто першоджерелами, вибір яких визначається історичним періодом, іншими обставинами. До третьої групи відносимо джерела особового походження, які становлять окрему важливу, подекуди основну, групу джерел біографічного дослідження. Структурно-функціональний аналіз джерел дослідження педагогічних персоналій, $з$ нашого погляду, передбачає розв'язання низки завдань: окреслення дефініцій, пов'язаних із ними понять і категорій; визначення підходів і критеріїв їхньої класифікації; з'ясування аспектів, які стосуються інформативності джерел, їхньої критики, репрезентативності джерельної бази тощо.

Вивчення джерелознавчих проблем педагогічної біографістики ускладнює іï міждисциплінарність. Це зумовлює потребу використання науково-методологічного інструментарію не лише історико-педагогічної науки (яка спирається на досвід історичної науки), а й інших галузей знань: біографістики, а також психології, соціології, лінгвістики тощо.

3 позицій історико-педагогічної науки джерелознавство розглядаємо як іï спеціальну галузь (дослідницький напрям, субдисципліну), що розробляє теорію i методику вивчення та використання джерел у працях 3 історії освіти, педагогічної думки, про педагогічні персоналії тощо. До його предметного поля включаємо комплекс проблем, які стосуються вивчення походження, складу, структури джерела; визначення теоретико-методологічних засад їхнього збору, систематизації, класифікації, критики, аналізу, синтезу; виявлення функціонально-пізнавальних можливостей джерельної бази кожного окремого дослідження та історикопедагогічної науки загалом.

Узагальнений аналіз репрезентативних історико-педагогічних та історичних студій засвідчує відсутність (зокрема й через їхню різнопрофільність) консолідованої позиції у визначенні базових категорій джерелознавства, однак дозволяє запропонувати їхні оптимальні дефініції в руслі досліджуваної проблеми.

Поняття “джерело” (як “першоджерело", “первинне джерело”) трактуємо як носія суспільно- і науково значущої інформації, що виникло як продукт історичного розвитку та відображає суть, зміст певного освітньо-педагогічного процесу, явища. Науковці правомірно вказують на відносність понять "первинне" i “вторинне" джерело, бо те, що є вторинним для одного дослідження може бути першоджерелом для іншого [1, с. 48-53]. Однак їх потрібно чітко розмежовувати 3 позицій джерелознавства та історіографіі.

Науковці часто пропонують загальні, дещо розмиті, трактування “історикопедагогічного джерела", приміром, як “пам'ятки духовної і матеріальної культури, що відображають людську діяльність” [3, с. 146], та ін. Сприйнятливим вважаємо його визначення як продукту соціальної діяльності, що несе у вигляді певної знакової системи інформацію про процеси навчання і виховання та має всі потенційні умови для іï включення і закріплення в системі історико-педагогічних знань Д. Раскін [8]. 
Утім, поняття "біографічне джерело" залишається не розробленим у біографістиці та гуманітаристики загалом, тому зазвичай уживається у словосполученні 3 різними видами джерел особового походження (автобіографія, мемуари, листування тощо) або як їхній синонім. Водночас поняття “джерело", “історико-педагогічне джерело" мають особливе інформаційне навантаження в педагогічній біографістиці. Це зумовлено їхньою “суб”єктивно-об'єктивною” природою: 3 одного боку, кожне історико-педагогічне джерело суб'єктивне, позаяк $€$ продуктом людської діяльності, 3 іншого, воно здатне об'єктивно відображати історичну дійсність та життедіяльність особи, ії внутрішній світ, творчі і професій здобутки тощо.

Від означених відрізняємо поняття “джерельна інформація", під якою, 3 позицій педагогічної біографістики, розумісмо присутність у джерелі різних типів інформації та стійких зв'язків між ними, які забезпечують його цілісність і здатність бути основою для здобуття науково обгрунтованого знання про різні аспекти життя, діяльності, творчості педагогічної персоналії. Особливості формування i використання джерельної інформації полягають у тому, що, відображаючи процеси в певному соціокультурному середовищі (родинному, освітньому, професійному тощо), вона стає об'єктом дослідження, дозволяє біографові розв'язувати певні дослідницькі завдання.

Об'єктивно науковців цікавлять усі види інформації, утім, залежно від мети конкретного дослідження, вони мають вирішувати, який вид інформації $\epsilon$ важливим i відповідно до цього добирати джерела, що містять потрібні відомості. При цьому враховуються особливості різних видів джерельної інформації, яка може бути: а) відкритою (випливає із зовнішніх, формальних ознак джерела); б) закритою, латентною (коли, до прикладу, у мемуарних творах замовчуються або перекручуються факти, ігноруються реаліі); в) прихованою (через різні обставини життя, професійної і громадської діяльності); г) прямою і побічною (що безпосередньо або опосередковано стосується досліджуваної персоналії); г) актуалізованою (яку автор вилучає, аналізує й використовує в дослідженні); д) потенційною (спочатку відкладеною, а згодом залученою для розширення оціночних характеристик) тощо.

Біограф має розуміти умовність і практичну невичерпність обсягу джерельної інформації навіть щодо конкретного педагогічного дослідження, тож повинен віднайти той баланс, “золоту середину”, які засвідчують ії достатність для всебічного вивчення персоналії. У такому ключі актуалізуємо поняття "джерельна база", яке розглядаємо у двох значеннях: “широкому” - як сукупність джерел, на які спирається історико-педагогічна наука, та "вузькому" (“джерельний корпус") - як комплекс нагромаджених, систематизованих і проаналізованих автором різновидових неопублікованих і опублікованих джерел для розв'язання науково-дослідницьких завдань.

Однією зі стрижневих проблем теорії і практики історико-педагогічного джерелознавства є класифікація джерельного комплексу. Труднощі іiі розробки пов'язані з необхідністю охопити всю сукупність джерел певного дослідження, запропонувавши їхню цілісну, науково обгрунтовану, логічну пов'язану систему поділу на типи, види, різновиди тощо. При з'ясуванні цієї проблеми апелюємо до науково-теоретичного досвіду історичного джерелознавства (О. Богдашина, М. Варшавчик, Я. Калакура, С. Макарчук, О. Ясь та ін.), хоча й історико-педагогічна наука має певні напрацювання в цьому напрямі (O. Адаменко, Г. Бєлан, О. Голубнича, О. Петренко, О. Сухомлинська та ін.). 
Висновки та перспективи подальших досліджень. Отже, у руслі нашого дослідження класифікацію джерел педагогічної біографістики розглядаємо 3 двох позицій: а) як метод і механізм їхнього поділу за певними спільними ознаками; б) як дослідницьку технологію, що охоплює основні функції джерелознавства (пошук, виявлення, аналіз, систематизація, критика джерел), етапи наукової роботи 3 джерелами, обгрунтовує їхній добір, опрацювання й використання. Подальшого дослідження потребує розробка понять "біографічне джерело”, “джерело”, "історикопедагогічне джерело", що мають особливе інформаційне навантаження в педагогічній біографістиці.

\section{Література}

1. Адаменко О. А. Использование технологии персонифицированого подхода в подготовке преподавателей высией школы. Zbiór raportow naukowych. "Science - od teorii do praktyki". (29.03.2013 - 31.03.2013). Sopot: Wydawca: Sp.zo.o. "Diamond trading tour", 2013. S. 48 - 53.

2. Анисов М. И. Источники изучения истории советской иколь и педагогики: учеб.-метод. пособ. для пед. ин-тов. М.: Просвещение, 1986. $223 \mathrm{c}$.

3. Васильев К. И. Работа с архивными материалом. Методы педагогического исследования. М. Просвещение, 1972. $159 \mathrm{c}$.

4. Голубнича Л.О. Класифікація джерел педагогічних персоналей. Педагогічний дискурс: зб. наук. прачь / гол. ред. І.М. Шоробура. Хмельницький: ХГПА, 2013. Вип. 15. С. 162 - 167.

5. Гупан Н.М. Розвиток історії педагогіки в Україні (Історіографічний аспект). автореф. дис. ... док. пед. наук: 13.00 .01$. К., 2001. 38 с.

6. Днепров Э. Л. Становление и развитие отечественной истории педагогики: основные этапы и тенденции; историографические и методологические проблемы изучения отечественной школы и педагогики. М., 1989. 254 с.

7. Петренко О. Б. До проблеми класифікації джерельної бази історико-педагогічного дослідження. Педагогічний дискурс. 2013. Вип. 15. С. 536-541.

8. Раскин Д. И. Классификация историко-педагогических источников. Историографические $и$ методологические проблемы изучения истории отечественной иколы и педагогики. М., 1989. C. $85-98$.

9. Стражнікова I. Розвиток педагогічної науки в дослідженнях Західного регіону України другої половини XX - початку XXI століття: історіографічний контекст. Івано-Франківськ: НАIP, $2015.616 \mathrm{c}$

10. Сухомлинська О.В. Історико-педагогічний прочес: нові підходи до загальних проблем. К.: А.П.Н., 2003. $68 \mathrm{c}$.

\section{References}

1. Adamenko O. A. Yspolzovanye tekhnolohyy personyfytsyrovanoho podkhoda $\mathrm{v}$ podhotovke prepodavatelei vyisshei shkolyi [The use of technology personalized approach in the preparation of high school teachers]. Zbiór raportow naukowych. "Science - od teorii do praktyki". (29.03.2013 31.03.2013). Sopot: Wydawca: Sp.zo.o. "Diamond trading tour", 2013. S. $48-53$.

2. Anysov M. Y. Ystochnyky yzuchenyia ystoryy sovetskoi shkolyi y pedahohyky: ucheb.-metod. posob. dlia ped. yn-tov [Sources of study of the history of the Soviet school and pedagogy: studies. Method. benefit for ped. in-tov.7. M.: Prosveshchenye, 1986. $223 \mathrm{~s}$.

3. Vasylev K. Y. Rabota s arkhyvnyim materyalom [Work with archival material]. Metodyi pedahohycheskoho yssledovanyia. M. : Prosveshchenye, 1972. $159 \mathrm{~s}$.

4. Holubnycha L. O. Klasyfikatsiia dzherel pedahohichnykh personalei [Classification of sources of pedagogical personnel]. Pedagogical discourse. 2013. Vyp. 15. S. 162 - 167.

5. Hupan N. M. Rozvytok istorii pedahohiky v Ukraini (Istoriohrafichnyi aspekt) [Development of the history of pedagogy in Ukraine (Historiographical aspect)] avtoref. dys. ... dok. ped. nauk: 13.00.01. K., $2001.38 \mathrm{~s}$.

6. Dneprov E. L. Stanovlenye y razvytye otechestvennoi ystoryy pedahohyky: osnovnyie эtapyi y tendentsyy; ystoryohrafycheskye y metodolohycheskye problemyi yzuchenyia otechestvennoi shkolyi y pedahohyky [Formation and development of the national history of pedagogy: the main stages and trends; historiographic and methodological problems of the study of the native school and pedagogy]. M., 1989. $254 \mathrm{~s}$. 
7. Petrenko O.B. Do problemy klasyfikatsii dzherelnoi bazy istoryko-pedahohichnoho doslidzhennia. Pedahohichnyi dyskurs [To the problem of classification of the source base of historical and pedagogical research]. Pedagogical discourse. 2013. Vyp. 15. S. 536-541.

8. Raskyn D.Y. Klassyfykatsyia ystoryko-pedahohycheskykh ystochnykov [Classification of historical and pedagogical sources]. Historiographical and methodological problems of studying the history of the native school and pedagogy. M., 1989. S. $85-98$.

9. Strazhnikova I. Rozvytok pedahohichnoi nauky v doslidzhenniakh Zakhidnoho rehionu Ukrainy druhoi polovyny KhKh - pochatku KhKhI stolittia: istoriohrafichnyi kontekst [The development of pedagogical science in the researches of the Western region of Ukraine in the second half of the 20th the beginning of the 21st century: the historiographical context]. Ivano-Frankivsk: NAIR, 2015. $616 \mathrm{~s}$.

10. Sukhomlynska O.V. Istoryko-pedahohichnyi protses: novi pidkhody do zahalnykh problem [Historical and pedagogical process: new approaches to common problems]. K., 2003. $68 \mathrm{~s}$.

Одержано статтю: 7.02.2019

Прийнято до друку: 21.03.2019

УДК $37.015 .31: 27-42$

DOI: $10.15330 /$ esu. $15.51-59$

\section{Наталія Салига,}

кандидат педагогічних наук, доцент, ДВНЗ “Прикарпатський національний університет імені Василя Стефаника" (м. Івано-Франківськ, Україна)

Nataliia Salyha, Candidate of pedagogical scienses $(\mathrm{PhD})$, Assosiate Proffesor, Vasyl Stefanyc Precarpathian National University (Ivano-Frankivsk, Ukraine) natalii58@ukr.net

\section{ПОГЛЯДИ ІОАННА ПАВЛА І НА ПРОБЛЕМИ ВИХОВАННЯ ДІТЕЙ ТА МОЛОДІ НА ЗАСАДАХ ХРИСТИЯНСЬКОЇ МОРАЛІ}

\section{VIEWS OF JOHN PAUL II ON THE PROBLEMS OF CHILD AND YOUTH EDUCATION FROM THE STANDPOINT OF CHRISTIAN MORALITY}

Стаття присвячена проблемі виховання дітей та молоді з позиџій християнської моралі у творчості та просвітницькій діяльності Папи Римського Іоанна Павла II, який був не лиие видатною духовною особою, дипломатом, психологом, філософом, істориком, а й справжнім педагогом світу, одним із найбільи харизматичних діячів ХХ cm. У статті розглянуто філософсько-педагогічні прачі вченого, проаналізовано гуманістичну сутність $i$ зміст його ідей, розкрито загальнолюдське значення його духовної спадчини в реалізації ідей християнськой моралі сучасної молоді.

Ключові слова: мораль, християнська мораль, виховання, Іоанн Павло II.

The article focuses on the problem of educating children and young people from the standpoint of Christian morality in the works and educational activities of Pope John Paul II who was not only a prominent clergyman, diplomat, psychologist, philosopher, historian, but a true teacher of the world, one of the most charismatic leaders of the 20th century. It deals with the philosophical and pedagogical works of the scientist, analyzes the humanistic core and content of his ideas, reveals the universal significance of his spiritual heritage in implementing the ideas of Christian morals of modern youth.

John Paul II left behind a wealth of scientific achievements. Most members of the Ukrainian scientific community know him only as the Pope, the leader of the Catholic Church. However, it would be a big mistake to limit this figure to religious activity only. Among the rich creative heritage of the Pontiff, there are works that have a direct bearing on pedagogy. The views of John Paul II on the education of children and young people from the standpoint of Christian morality are reflected in voluminous pastoral teachings, apostolic messages, 